International Journal of Fuzzy Logic Systems (IJFLS) Vol.6, No.2,April 2016

\title{
IMPLEMENTATION OF FUZZY CONTROLLED Photo Voltaic Fed Dynamic Voltage Restorer to Mitigate Power Quality PROBLEMS
}

\author{
K R Sudha ${ }^{1}$ and K Padmavathi ${ }^{2}$ \\ ${ }^{1}$ Professor, Department of Electrical Engineering, Andhra University, Visakhapatnam, \\ Andhra Pradesh, India \\ and \\ ${ }^{2}$ Research Scholar, JNTU, Kakinada, Andhra Pradesh, India
}

\begin{abstract}
Power Quality $(P Q)$ has become an area of concern in the electrical distribution system. Dynamic Voltage Restorer $(D V R)$ restores load voltage to a nominal balanced sinusoidal voltage, when the source voltage has harmonic distortions, sag, swell and unbalances. In this paper a Photo Voltaic(PV) fed DVR is proposed to mitigate $P Q$ problems. The $P V$ system can supply the maximum power to the load at a particular operating point known as Maximum Power Point (MPP), at which the entire PV system operates with maximum efficiency. A Fuzzy Controller based MPPT is implemented to generate the optimal voltage from the photovoltaic system by modulating the duty cycle applied to the boost converter. The DVR is implemented using a Fuzzy Logic Controller based voltage source inverter with Photovoltaic system. The test system has been simulated and the efficacy of the proposed PV based Fuzzy controlled DVR is compared with Proportional Integral (PI) controlled DVR.
\end{abstract}

\section{KEYWORDS}

Power Quality, Dynamic Voltage Restorer, Photo Voltaic System, Synchronous Reference Frame, Maximum Power Point Tracking, Fuzzy Controller

\section{INTRODUCTION}

The requirement of the electrical power is increasing and in tandem the problems while transmitting the power through the distribution system are also increasing. In the recent years, Power Quality (PQ) problems in the distribution system and their solutions have received much attention. Power Quality is defined as the index which both the delivery and consumption of electric power affects on the performance of electrical apparatus [1]. A Dynamic Voltage Restorer (DVR) is a custom power device which is used to mitigate the voltage sags by injecting

DOI : $10.5121 /$ ijfls.2016.6203 
International Journal of Fuzzy Logic Systems (IJFLS) Vol.6, No.2,April 2016

voltage into the system. Voltage deviations, often in the form of voltage sags, swells can cause awful disruption and results in ample economic loss. A Dynamic Voltage Restorer is connected in series to the system which is used to protect the sensitive loads from voltage deviations [2]. The divergence in the voltage is caused due to short circuits or faults, switching on or off heavy loads, energizing a large capacitor bank, motors starting. DVR injects voltage to mollify voltage sag and swell. DVR requires a high capacity DC storage system. When the DVR is used for voltage compensation, it supplies real power requirements of the system. In this paper, the DC is supplied by using photo voltaic system. The benefits of using photovoltaic system are (i) operate with little maintenance, (b) pollution free, (c) reduced production end wastes and emissions [3]. The installation of photovoltaic system requires high initial capital cost, but the operating cost is low compared with obtainable power technologies. The efficiency of a solar cell is very stumpy. Maximum Power Point Tracking (MPPT) method is used to increase the efficiency of solar cell [4]. From a varying source, Maximum Possible Power (MPP) is achieved by using this technique. Many classic methods and controllers have been widely developed and implemented to track the MPP [5]. In this paper the MPPT using fuzzy logic for PV system is presented. In photovoltaic system the I-V curve is non-linear, thereby making it difficult to be used to power a certain load. To overcome this intricacy, a boost converter is employed whose duty cycle is varied by using FLC based MPPT algorithm. Boost converters are used to convert low voltage to high voltage by using power electronic devices, inductors and capacitors. [6]. This paper also presents the Photo Voltaic fed DVR using fuzzy logic controller in the control unit of Voltage Source Inverter(VSI). FLC provides gating signals for voltage source inverter control. The proposed DVR is capable of compensating the power quality problems and maintained a prescribed voltage at the load terminals. The performance of the proposed PV fed DVR using Fuzzy Logic is compared with Proportional Integral (PI) controller.

\section{Power Quality Problems}

Power Quality (PQ) is concerned with deviations of voltage, current and frequency from the ideal conditions, which results in malfunction of end-use equipment. Typical Power Quality problems originating in the distribution system are voltage sags, swells, unbalance, harmonics and interruptions. These PQ problems generally are not due to system faults, but are caused by the load variations on the system, system switching operations, and poorly designed or old systems [7]. Voltage Sag is a sudden diminution of the voltage at a point in the electrical system, followed by voltage recovery after a short period, from half a cycle to a few seconds. Sag is defined as a reduction between 0.1 and 0.9 pu in rms voltage or current at the power frequency for durations of 0.5 cycles to 1 minute. The causes of sag are electrical faults such as 3 - phase, line-to-line, or single line-to-ground [8]. And also weather (lightning, wind, ice), falling or contact with tree branches, contamination of insulators, animal contact can result in voltage sags. Voltage swell is defined as increase to between $1.1 \mathrm{pu}$ and $1.8 \mathrm{pu}$ in rms voltage or current at thepower frequency durations from 0.5 to 1 minute. A swell can occur due to a single line-toground fault on the system, which can also result in a temporary voltage rise on the unfaulted phases. Sudden load reduction and switching on of capacitor banks are also caused of swell. Interruption An interruption occurs when the supply voltage or load current decreases to less than $0.1 \mathrm{pu}$ for a period of time not exceeding $1 \mathrm{~min}$. Harmonics are sinusoidal voltages or currents with frequencies which are integer multiples of the power system frequency. Non linear loads, 
loads generating electric arc, residential loads with switch mode power supplies are the causes of harmonics. Various power quality problems are shown in Fig.1.

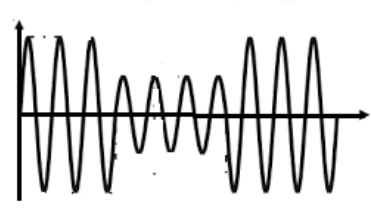

SAG

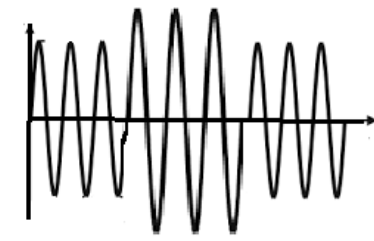

SWELL

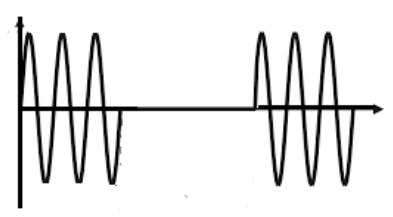

INTERRUPTION

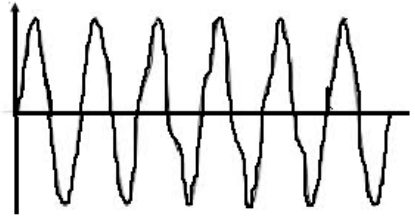

HARMONICS

Figure 1. Power Quality problems

\section{DynAmic Voltage Restorer}

The utility must design, maintain, and operate the power system while minimizing power quality problems. The Dynamic Voltage Restorer (DVR) is designed to compensate voltage sag by inserting a voltage in series with the distribution supply mains. The magnitude and phase of the inserted voltage can compensate the voltage sag caused by the upstream distribution network disturbance. A complete DVR system contains several parts [9] .They are Photo Voltaic system (energy storage), Voltage Source Inverter (VSI), filter unit, Injection Transformer. The compensating voltage is injected in series with the distribution feeder. The block diagram of test system connected with Photo Voltaic fed Dynamic Voltage Restorer shown in Fig. 2.

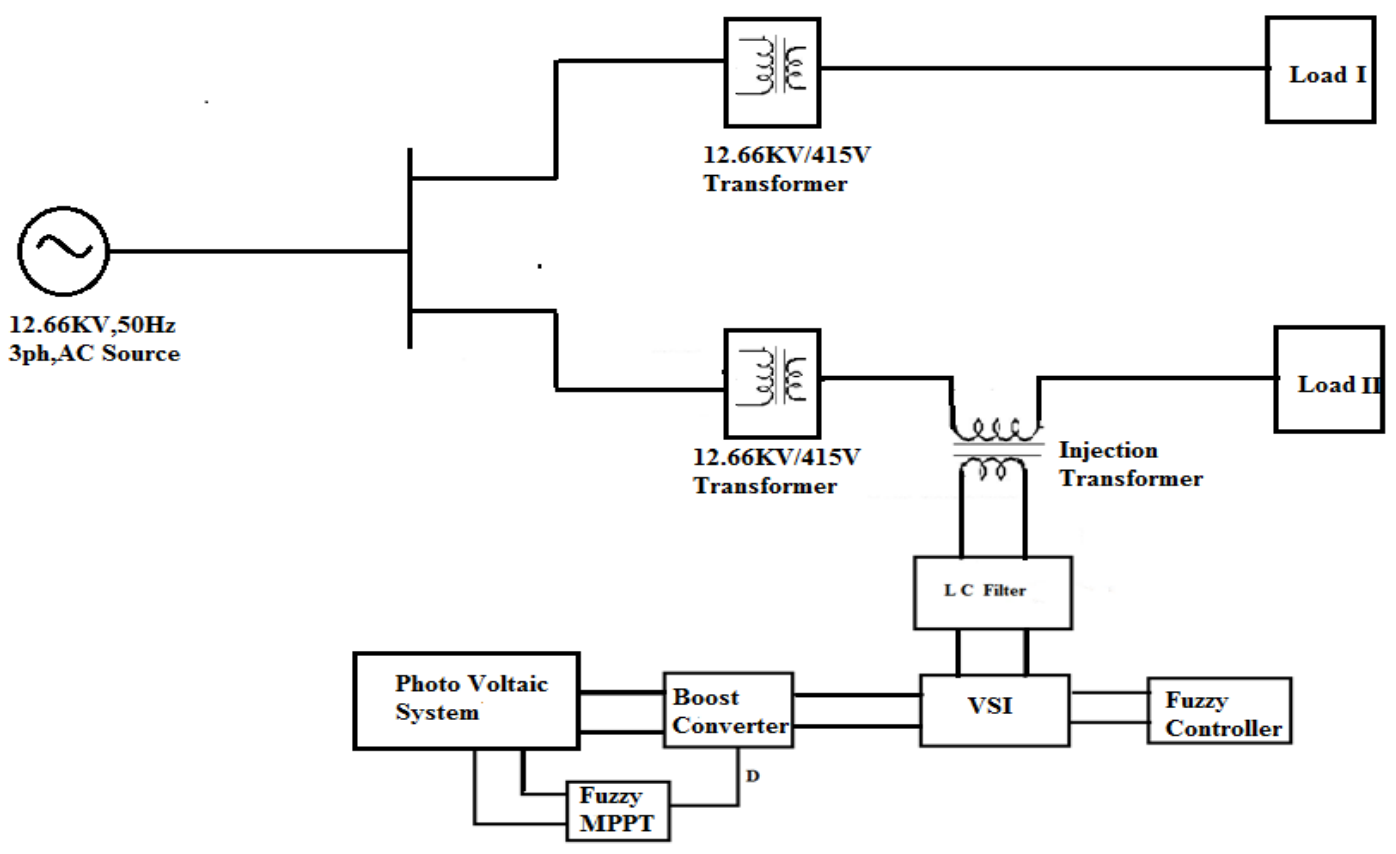


Figure 2. Block Diagram of proposed DVR Configuration System

The DVR injects voltage in the distribution feeder such that the feeder voltage perfectly regulated at system nominal voltage and phase angle. The voltage source Inverter (VSI) is connected to Photo Voltaic System through DC-DC Boost Converter. The injected voltage of the DVR is represented by Eq.(1)

$V_{d v r}=V_{L}+\left(R_{L}+j X_{L}\right) I_{L}-V_{f}$

Where $V_{d v r}$ is series injected voltage of the DVR. $V_{L}$ is the desired magnitude of the voltage. $R_{L} \&$ $X_{L}$ are the resistance and reactance of the line respectively. $I_{L}$ is the current flowing in the line; $V_{f}$ is the node voltage during fault condition. The complex power injection of the DVR is given in Eq.(2)

$\mathrm{S}_{\mathrm{dvr}}=\mathrm{V}_{\mathrm{dvr}} \mathrm{I}_{\mathrm{L}}^{*}$

\subsection{Control Strategy of DVR}

Synchronous Reference Frame (SRF) theory is used to generate reference voltage signal which is based on Park's Transformation method. The stationary frame quantities $(a, b, c)$ are transformed into synchronous rotating frame(d,q,o). In this method, the angular position of the reference frame rotating at a constant speed in synchronism with the three-phase ac voltage is known as transformation angle $(\omega t)$. The transformation angle $(\mathrm{wt})$ is generated by using Phase Locked Loop(PLL). Fig.3 shows the control strategy of proposed DVR.

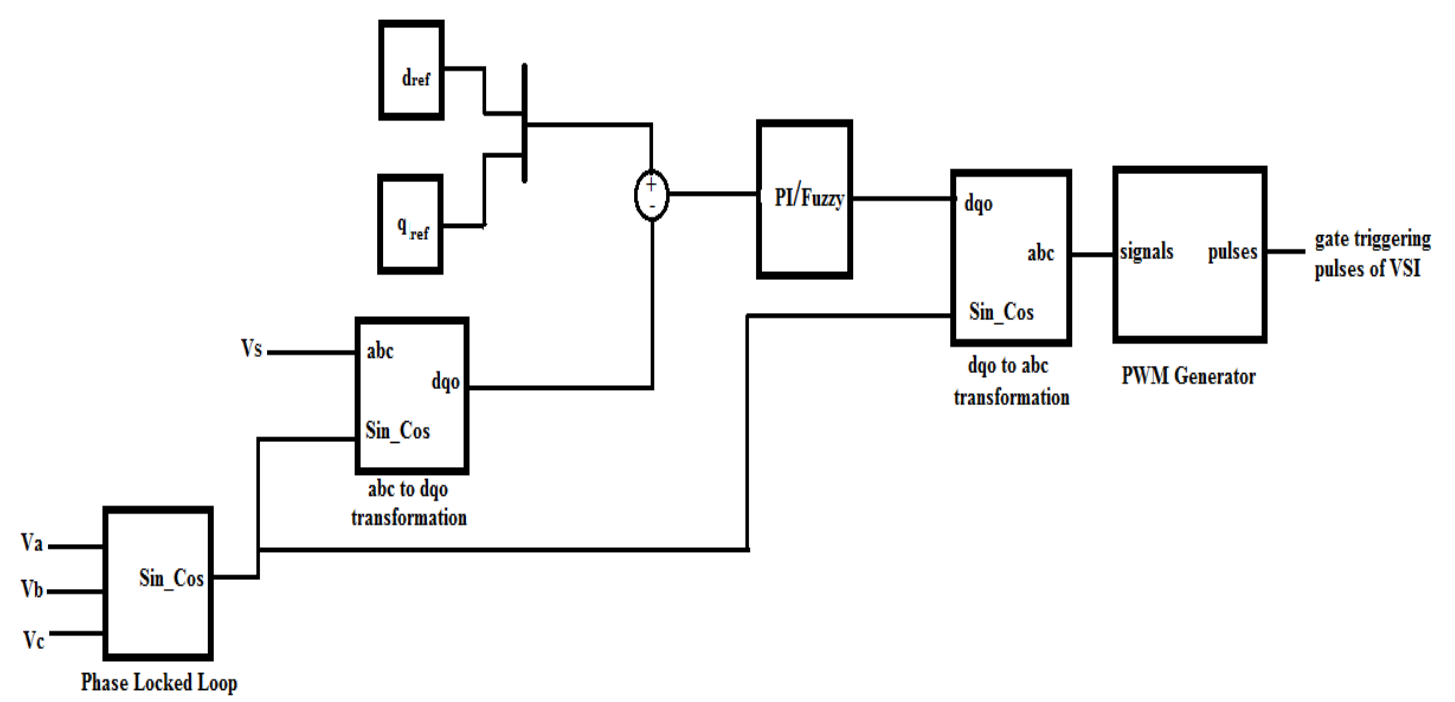

Figure 3. Control block diagram of DVR 
Active and reactive power can be controlled by controlling dq components[10]. The power invariant version of transforming three phase ac supply voltage into d-q-o and inverse transform are shown in Eq.(3) \& Eq.(4)

$$
\begin{aligned}
& {\left[\begin{array}{c}
V_{d} \\
V_{q} \\
V_{0}
\end{array}\right]=\sqrt{2 / 3}\left[\begin{array}{ccc}
\cos (w t) & \cos \left(w t-\frac{2 \pi}{3}\right) & \cos \left(w t+\frac{2 \pi}{3}\right) \\
-\sin (w t) & -\sin \left(w t-\frac{2 \pi}{3}\right) & -\sin \left(w t+\frac{2 \pi}{3}\right) \\
1 / \sqrt{2} & 1 / \sqrt{2} & 1 / \sqrt{2}
\end{array}\right]\left[\begin{array}{l}
V_{a} \\
V_{b} \\
V_{c}
\end{array}\right]} \\
& {\left[\begin{array}{c}
V_{a} \\
V_{b} \\
V_{c}
\end{array}\right]=\sqrt{2 / 3}\left[\begin{array}{ccc}
\cos (w t) & -\sin w t & \frac{\sqrt{2}}{2} \\
\cos \left(w t-\frac{2 \pi}{3}\right) & -\sin \left(w t-\frac{2 \pi}{3}\right) & \frac{\sqrt{2}}{2} \\
\cos \left(w t+\frac{2 \pi}{3}\right) & -\sin \left(w t+\frac{2 \pi}{3}\right) & \frac{\sqrt{2}}{2}
\end{array}\right]\left[\begin{array}{c}
V_{d} \\
V_{q} \\
V_{0}
\end{array}\right]}
\end{aligned}
$$

The error calculated from the comparison between reference and measured quantities is applied to $\mathrm{PI} /$ Fuzzy controller and the inverse transform is executed. The compensated voltages are applied to Sinusoidal Pulse Width Modulation (SPWM) to generate gate pulses of the VSI of proposed DVR.

\section{Modeling of Photo Voltaic System}

Renewable energy sources consume the finite resources of the earth and can be quickly replenished. The potential of renewable energy sources is enormous as they can meet the world's energy demand. Even more importantly, renewable energy produces little or no waste products such as carbon dioxide or other chemical pollutants, so has minimal impact on the environment. One major advantage with the use of renewable energy is that as it is renewable it is therefore sustainable and so will never run out. Renewable energy sources such as biomass, wind, solar, hydropower, and geothermal can provide sustainable energy services.

In contributing the generation of electrical energy, renewable energy sources are playing vital role. A Photovoltaic (PV) produces electricity in a clean and reliable manner. Devoid of creating any pollution PV system converts sunlight directly into electrical energy. The sun's light energy can be converted directly into electricity in a single process using Photovoltaic (PV) cells, also known as solar cells. A module is an interconnection of number of individual PV cells in a sealed, weatherproof package [11]. Two are more modules are connected in series to increase the voltage and in parallel to increase the current. To achieve desired output, PV modules are connected in series and parallel which is known as PV array. The benefits of using photovoltaic system are (i) operate with little maintenance, (b) pollution free, (c) reduced production end wastes and emissions. The photovoltaic cell output voltage is a function of photocurrent which is determined by load current depending on the solar irradiation level during the operation. Fig. 4 shows the equivalent circuit of photo voltaic cell. 


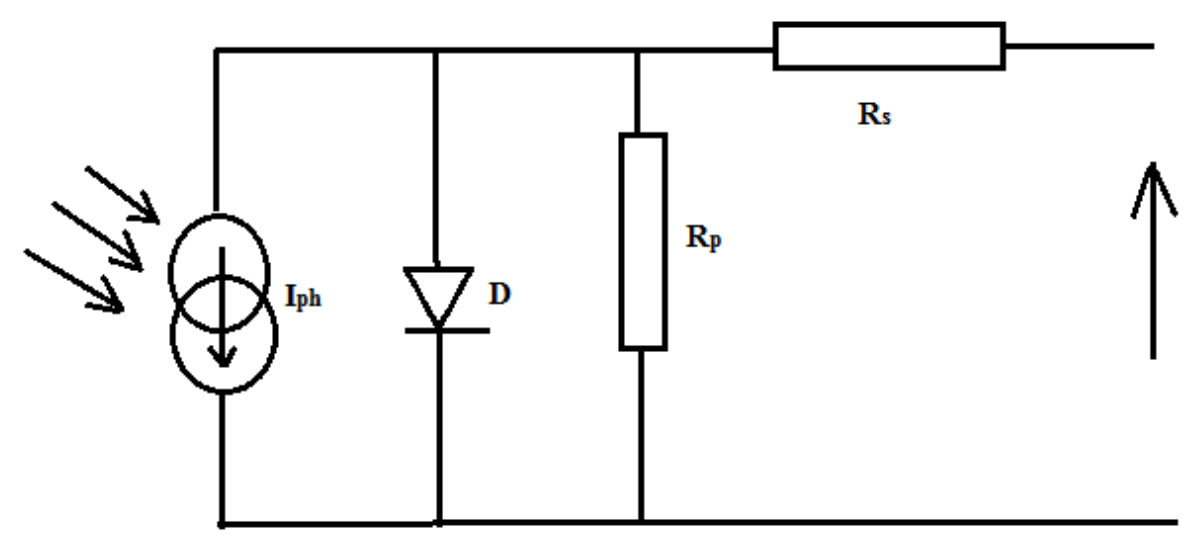

Figure 4. Photo Voltaic circuit model

The array voltage is

$$
\begin{aligned}
& \mathrm{V}_{\mathrm{pv}}=\left(\mathrm{N}_{\mathrm{s}} \mathrm{TAK} / \mathrm{q}\right) * \ln \left(\left[\mathrm{N}_{\mathrm{p}} \mathrm{I}_{\mathrm{ph}}-\mathrm{I}_{\mathrm{pv}}+\mathrm{N}_{\mathrm{p}} \mathrm{I}_{\mathrm{o}}\right] / \mathrm{I}_{\mathrm{o}}\right) \\
& \mathrm{I}_{\mathrm{pv}}=\mathrm{N}_{\mathrm{p}} \mathrm{I}_{\mathrm{ph}}-\mathrm{N}_{\mathrm{p}} \mathrm{I}_{\mathrm{s}}\left[\exp \left(\mathrm{q}\left(\mathrm{V}_{\mathrm{PV}}+\mathrm{I}_{\mathrm{pv}} \mathrm{R}_{\mathrm{s}}\right) / \mathrm{N}_{\mathrm{s}} \mathrm{AKT}\right)-1\right]-\frac{\left(\mathrm{V}_{\mathrm{pv}}+\mathrm{R}_{\mathrm{s}} \mathrm{I}\right)}{\mathrm{R}_{\mathrm{p}}}
\end{aligned}
$$

Where $N_{p} \& N_{S}$ are the number of parallel and series cells respectively, $I_{p h}$ is the photocurrent, $I_{s}$ is the reverse saturation current of the diode, $\mathrm{q}$ is the charge of electron, $\mathrm{K}$ is the Boltzmann's constant, $T$ is the operating temperature, $A$ is fitting factor, $R_{s} \& R_{P}$ are series and shunt resistances of the cell respectively.

The output power of the photo voltaic array is given Eq. (7)

$\mathrm{P}_{\mathrm{pv}}=\mathrm{V}_{\mathrm{pv}} \mathrm{I}_{\mathrm{pv}}$

The photo current Iph depends on the solar radiation and cell temperature is shown in Eq. (8)

$\mathrm{I}_{\mathrm{ph}}=\left(\mathrm{I}_{\mathrm{scr}}+\mathrm{K}_{\mathrm{i}}\left(\mathrm{T}-\mathrm{T}_{\mathrm{r}}\right)\right) *(\mathrm{G} / 1000)$

Where $K_{i}$ is temperature coefficient of the cell's short circuit current, $G$ is the solar radiation in $\mathrm{W} / \mathrm{m}^{2}$.

The PV cell saturation current $I_{s}$ varies with temperature according to the following Eq. (9) 
$\mathrm{I}_{\mathrm{S}}=\mathrm{I}_{\mathrm{or}}\left[\mathrm{T} / \mathrm{T}_{\mathrm{r}}\right]^{3} \exp \left(\mathrm{q} \frac{\mathrm{E}_{\mathrm{g}}}{\mathrm{KA}}\left[\left(1 / \mathrm{T}_{\mathrm{r}}\right)-(1 / \mathrm{T})\right]\right)$

Where $\mathrm{T}$ is the operating temperature, $\mathrm{T}_{\mathrm{r}}$ is the cell reference temperature, $\mathrm{I}_{\mathrm{or}}$ is saturation current at $\mathrm{T}_{\mathrm{r}}$. Table 1 shows the parameters of photovoltaic system.

Table1. Photovoltaic System Parameters

\begin{tabular}{|l|l|l|}
\hline PV array parameters & Symbol & Values \\
\hline Cell Temperature & $\mathrm{T}$ & $25^{\circ} \mathrm{C}$ \\
\hline Reference Temperature & $\mathrm{T}_{\mathrm{r}}$ & $75^{\circ} \mathrm{C}$ \\
\hline Solar irradiance & $\mathrm{G}$ & $1000 \mathrm{~W} / \mathrm{m}^{2}$ \\
\hline $\begin{array}{l}\text { temperature coefficient of } \\
\text { the cell's short circuit } \\
\text { current }\end{array}$ & $\mathrm{K}_{\mathrm{i}}$ & $0.00023 \mathrm{~A} / \mathrm{K}$ \\
\hline $\begin{array}{l}\text { Cell short-circuit current at } \\
\mathrm{T}_{\mathrm{r}}\end{array}$ & $\mathrm{I}_{\mathrm{scr}}$ & $3.75 \mathrm{~A}$ \\
\hline $\begin{array}{l}\text { Saturation currentat } \\
\text { temperature } \mathrm{T}_{\mathrm{r}}\end{array}$ & $\mathrm{I}_{\mathrm{or}}$ & $0.000021 \mathrm{~A}$ \\
\hline Boltzmann constant & $\mathrm{K}$ & $1.38065 \mathrm{e}-23 \mathrm{~J} /{ }^{\circ} \mathrm{K}$ \\
\hline Charge of an electron & $\mathrm{Q}$ & $1.6022 \mathrm{e}-19 \mathrm{C}$ \\
\hline Fitting factor & $\mathrm{A}$ & 1.3 \\
\hline No. of parallel cells & $\mathrm{N}_{\mathrm{p}}$ & 6 \\
\hline No. of series cells & $\mathrm{N}_{\mathrm{s}}$ & 10 \\
\hline
\end{tabular}

\section{BoOst Converter}

Boost converter also called as high efficiency step- up converter which has an output DC voltage greater than its input DC voltage. The converter uses a Power Electronic Device, IGBT to pulse width modulate the voltage into an inductor. It consists of two semiconductor switches and one storage element. Fig.5 shows the circuit diagram of a boost converter. When the switch is closed, the inductor gets charged by the PV and stores the energy. The diode blocks the current flowing, so that the load current remains constant which is being supplied due to the discharging of the capacitor. When the switch is open the diode conducts and the energy stored in the inductor discharges and charges the capacitor. 


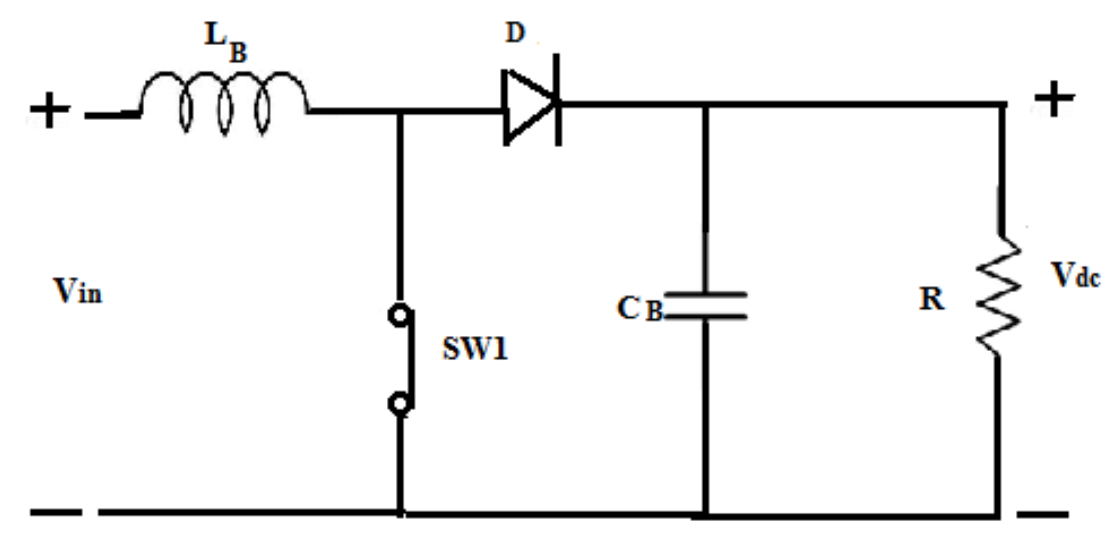

Figure 5. DC-DC Boost Converter

The output voltage of the boost converter can be written as

$\mathrm{V}_{\mathrm{dc}}=\operatorname{Vin}(1 /(1-\mathrm{D}))$

$\mathrm{V}_{\mathrm{dc}}$ is the output voltage of the boost converter, $\mathrm{V}_{\text {in }}$ is the input voltage of the boost converter, $\mathrm{D}$ is the Duty Cycle. The boost converter is used to maintain the output voltage constant for all the conditions of temperature and variations in solar irradiance. The switching frequency is chosen to $20 \mathrm{KHz}$. Hence the output voltage is correlated directly to the duty cycle of the pulses.

\subsection{Design of LC Parameters}

The inductor used in the boost converter is designed using Eq.(11)

$\mathrm{L}_{\mathrm{B}}=\mathrm{V}_{\mathrm{in}}\left(\mathrm{V}_{\mathrm{dc}}-\mathrm{V}_{\mathrm{in}}\right) / \Delta \mathrm{I}_{\mathrm{L}} \mathrm{f}_{\mathrm{s}} \mathrm{V}_{\mathrm{dc}}$

Where $f_{s}$ is the minimum switching frequency, $\Delta I_{L}$ is estimated inductor ripple current. A good estimation for the inductor ripple current is $20 \%$ to $40 \%$ of output current.

$$
\Delta \mathrm{I}_{\mathrm{L}}=(0.2 \text { to } 0.4) \mathrm{I}_{\mathrm{dc}(\max )} \mathrm{V}_{\text {out }} / \mathrm{V}_{\text {in }}
$$

The capacitor used in the converter is designed using Eq.(13)

$\mathrm{C}_{\mathrm{B}}=\mathrm{I}_{\text {out }(\max )} \mathrm{D} / \mathrm{f}_{\mathrm{s}} \Delta \mathrm{V}_{\text {out }}$

Where $\Delta V_{\text {out }}$ is the desired output ripple voltage. 


\section{6 . FuZzY Logic ConTroller}

Fuzzy logic is one of the most powerful control methods. Because of simplicity, handling nonlinearity and pact with fuzzy inputs, Fuzzy Logic Controllers (FLC) has been increased over the last decade [10]. The process of FLC can be classified into three stages: fuzzification, rule evaluation and defuzzification. Fuzzy algorithms are often robust, in the sense that they are not very sensitive to changing environments. System can operate much smoother using fuzzy logic for switching or tuning. In this paper, fuzzy logic controllers are used in photo voltaic system and in dynamic voltage restorer.

\subsection{Fuzzy Logic Based MPPT Controller}

To attain the maximum power from the solar photo voltaic system, FLC can be implemented as a Maximum Power Point Tracking (MPPT) controller [12]. The input variables are PV current and voltage and the output variable is duty cycle. Error (e) and change of error(ce) are calculated using the following

Eq.(14), Eq.(15), Eq.(16) and Eq.(17)

$\Delta \mathrm{I}_{\mathrm{pv}}=\mathrm{I}_{\mathrm{pv}}(\mathrm{t})-\mathrm{I}_{\mathrm{pv}}(\mathrm{t}-1)$

$\Delta \mathrm{V}_{\mathrm{pv}}=\mathrm{V}_{\mathrm{pv}}(\mathrm{t})-\mathrm{V}_{\mathrm{pv}}(\mathrm{t}-1)$

$\mathrm{e}(\mathrm{t})=\frac{\Delta \mathrm{I}_{\mathrm{pv}}}{\Delta \mathrm{V}_{\mathrm{pv}}}+\frac{\mathrm{I}_{\mathrm{pv}}}{\mathrm{v}_{\mathrm{pv}}}$

$c e(t)=e(t)-e(t-1)$

Where $\mathrm{I}_{\mathrm{pv}}$ and $\mathrm{V}_{\mathrm{pv}}$ are photo voltaic current and voltage, $\mathrm{t}$ and (t-1) are actual and previous states. The linguistic variables of both input and output membership functions are NB(negative big), NM(negative medium), NS(negative small),ZE(zero), PS(positive small), PM(positive medium), $\mathrm{PB}$ (positive big) are represented in Fig.6. The output variable, $d$ is the pulse width modulation signal to produce the switching pulses of the DC/DC converter. The rule base of the fuzzy logic controller used in PV system is represented by Table 2
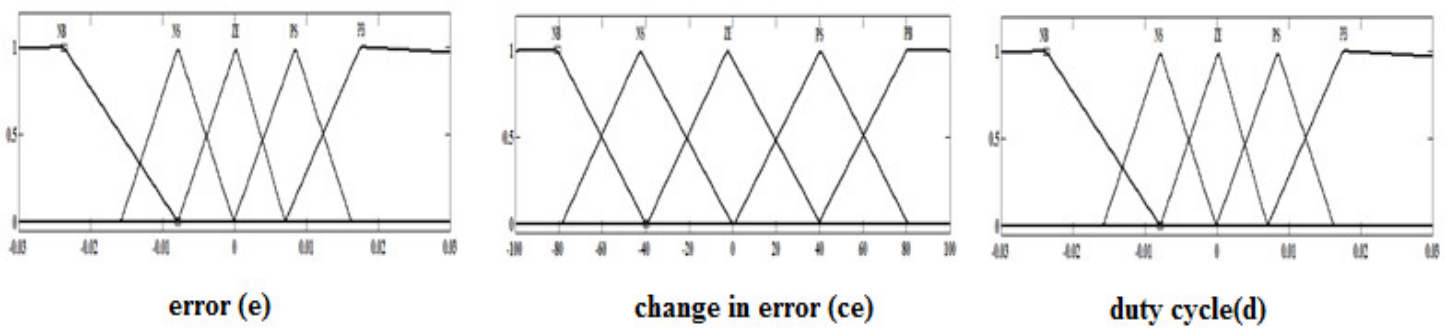

Figure 6. Membership Functions of input and output variables used in PV system 
Table 2. Rule base of fuzzy based MPPT controller

\begin{tabular}{|l|l|l|l|l|l|}
\hline e/ce & NB & NS & ZE & PS & PB \\
\hline NB & ZE & ZE & PB & PB & PB \\
\hline NS & ZE & ZE & PS & PS & PS \\
\hline ZE & PS & PS & ZE & ZE & NS \\
\hline PS & NS & NS & NS & ZE & ZE \\
\hline PB & NB & NB & NB & ZE & ZE \\
\hline
\end{tabular}

\subsection{Fuzzy Logic Based DVR Controller}

Inverter is the core constituent of DVR. The performance of the DVR is determined by the control strategy. The control system consists of the voltage correction method which determines the reference voltage that is to be injected by DVR. In this paper, Fuzzy Logic Controller (FLC) is employed for controlling the action of inverter of the proposed photovoltaic based DVR. The input variables are error and change in error[13]. Error is the difference between reference voltage $\left(\mathrm{V}_{\text {ref }}\right)$ and supply voltage (Vs) and shown in Eq.(18) \& Eq.(19)

$\operatorname{error}(E)=V_{\text {ref }}-V_{S}$

change of error $(D E)=E(t)-E(t-1)$

The output variables of FLC are the control signals that are used in generation of switching signals of the PWM inverter by comparing with a carrier signal. The typical member ship functions of input and output variables are shown in Fig.7. The set of 49 rules of FLC are shown in table 3
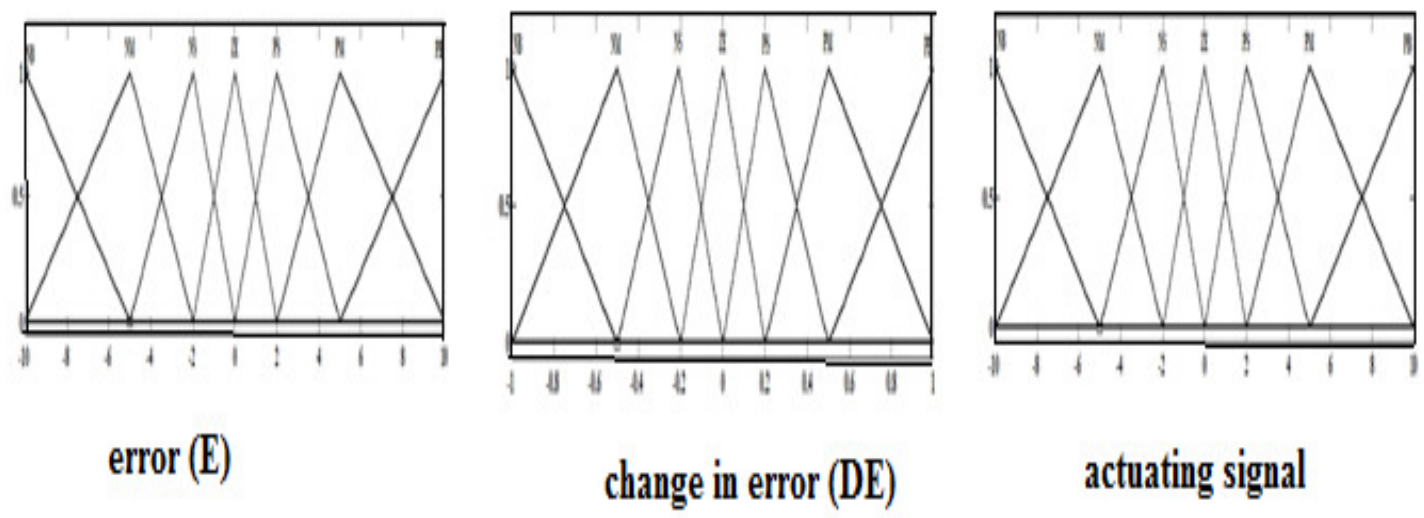

actuating signal

Figure 7. Membership Functions of input and output variables used in DVR 
International Journal of Fuzzy Logic Systems (IJFLS) Vol.6, No.2,April 2016

Table3. Rule base of fuzzy logic based DVR controller

\begin{tabular}{|l|l|l|l|l|l|l|l|}
\hline E/DE & NB & NM & NS & ZE & PS & PM & PB \\
\hline NB & NB & NB & NB & NM & NM & NS & ZE \\
\hline NM & NB & NB & NM & NM & NS & ZE & PS \\
\hline NS & NB & NM & NM & NS & ZE & PS & PM \\
\hline ZE & NM & NM & NS & ZE & PS & PM & PM \\
\hline PS & NM & NS & ZE & PS & PM & PM & PB \\
\hline PM & NS & ZE & PS & PM & PM & PB & PB \\
\hline PB & ZE & PS & PM & PM & PB & PB & PB \\
\hline
\end{tabular}

\section{Simulation Results:}

The performance of the proposed Dynamic Voltage Restorer is implemented on the test system is shown in Figure 1. The parameters of the test system and DVR are given in Table 4.

Table 4. System Parameters

\begin{tabular}{|c|c|c|}
\hline Sl.No & System Quantities & Values \\
\hline 1 & 3 phase Source & $\begin{array}{c}12.66 \mathrm{KV} \\
10 \mathrm{MVA}\end{array}$ \\
\hline 2 & 3-ph Transformer & $12.66 \mathrm{KV} / 400 \mathrm{~V}$ \\
\hline 2 & System Frequency & $50 \mathrm{~Hz}$ \\
\hline 3 & Line Impedance & $\mathrm{Ls}=100 \mathrm{mH}$ \\
\hline 4 & Filter Inductance & $\mathrm{Lf}=6 \mathrm{mH}$ \\
\hline 5 & Filter Capacitance & $\mathrm{Cf}=20 \mu \mathrm{F}$ \\
\hline \multirow[t]{4}{*}{6} & \multicolumn{2}{|c|}{ Load Details } \\
\hline & Active power & $2 \mathrm{KW}$ \\
\hline & Inductive Reactive Power & $0.4 \mathrm{KW}$ \\
\hline & Capacitive Reactive Power & $0.1 \mathrm{KW}$ \\
\hline 7 & Injection Transformer & $\begin{array}{c}\text { 10MVA, } \\
200 \mathrm{~V} / 500 \mathrm{~V}\end{array}$ \\
\hline 8 & Switching Frequency & $12.5 \mathrm{KHz}$ \\
\hline
\end{tabular}

According to the mathematical model, a sub model of the photovoltaic cell is implemented by using Matlab. The output characteristics are obtained under constant operating temperature and insolation are obtained. Typical characteristics of a PV module are shown in Fig 8 , Fig. $9 \&$ Fig. 10 
International Journal of Fuzzy Logic Systems (IJFLS) Vol.6, No.2,April 2016

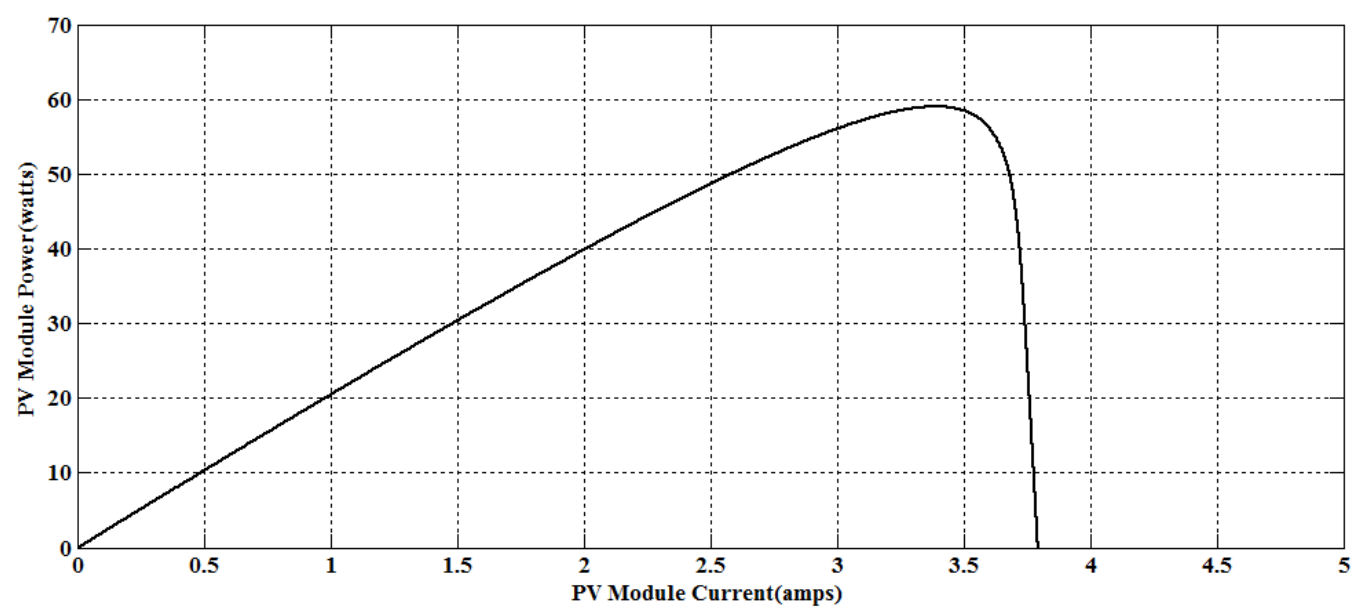

Figure 8. PI Characteristics of Photovoltaic system module

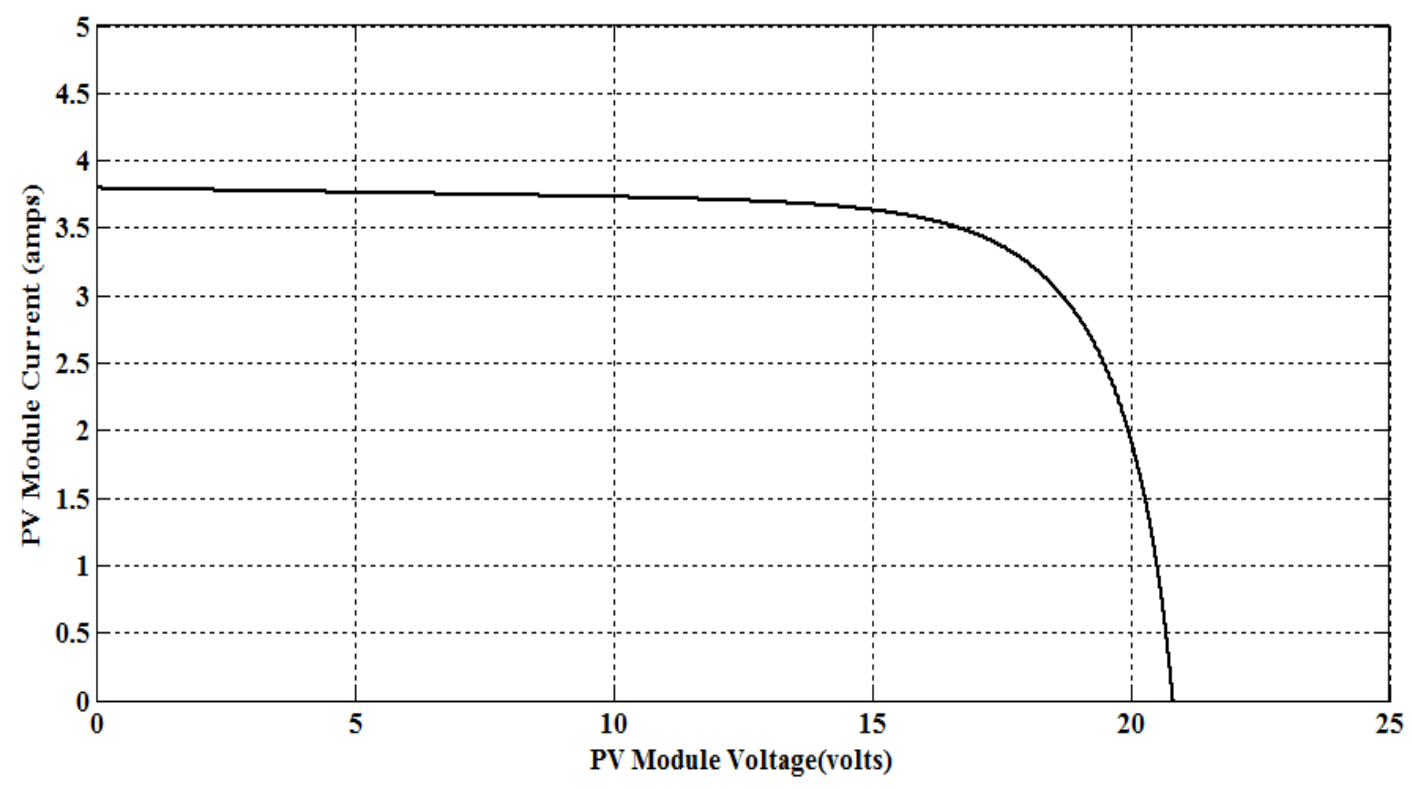

Figure 9. Characteristics of Photovoltaic system module 


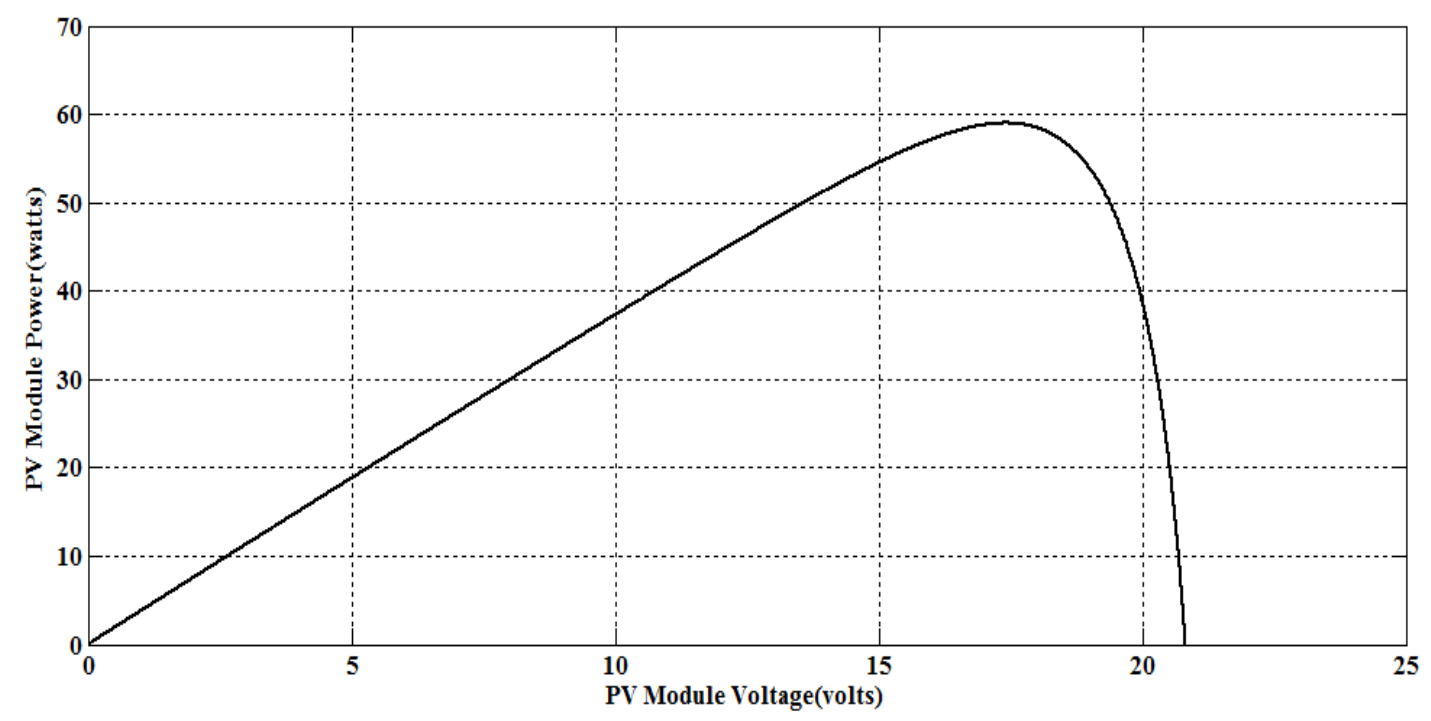

Figure 10. PV Characteristics of Photovoltaic system module

The output voltage is interfaced with boost converter. The converter is operated in continuous conduction mode. The voltage is step up to $200 \mathrm{~V}$, and this output is connected to the three phase inverter. The output voltage of the boost converter is shown in Fig. 11

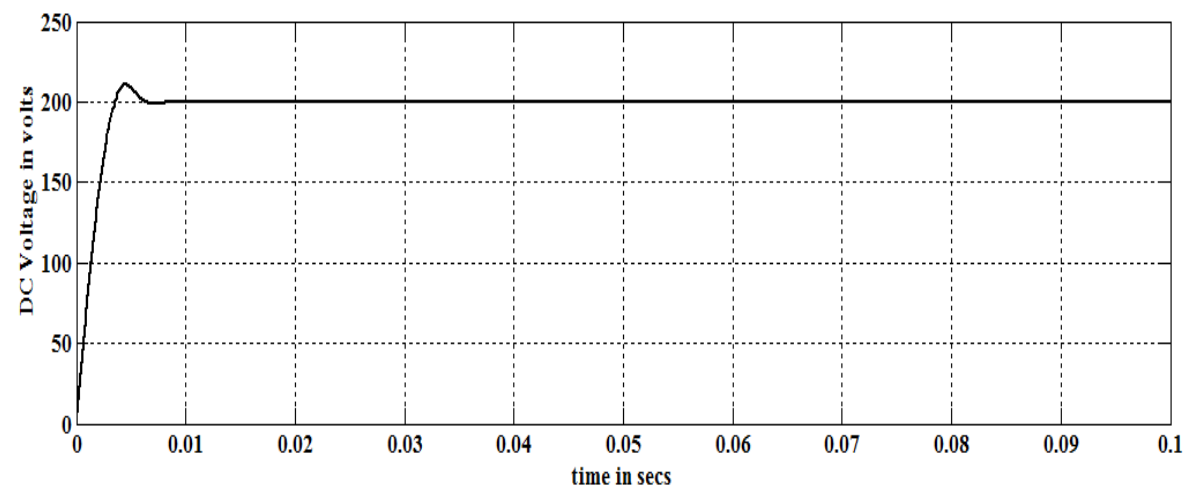

Figure 11. Magnitude of output DC voltage

The source voltage and load voltage magnitude is considered as $1.00 \mathrm{pu}$ during all calculations. As shown in fig, the test system is simulated with voltage sag, swell. Voltage sag is initiated at $0.02 \mathrm{sec}$ and it is kept until $0.09 \mathrm{sec}$ and voltage swell is simulated between $0.15 \mathrm{sec}$ and $0.19 \mathrm{sec}$. Fig. 12 shows the results of source voltage and load voltage by implementing PI controlled DVR. 


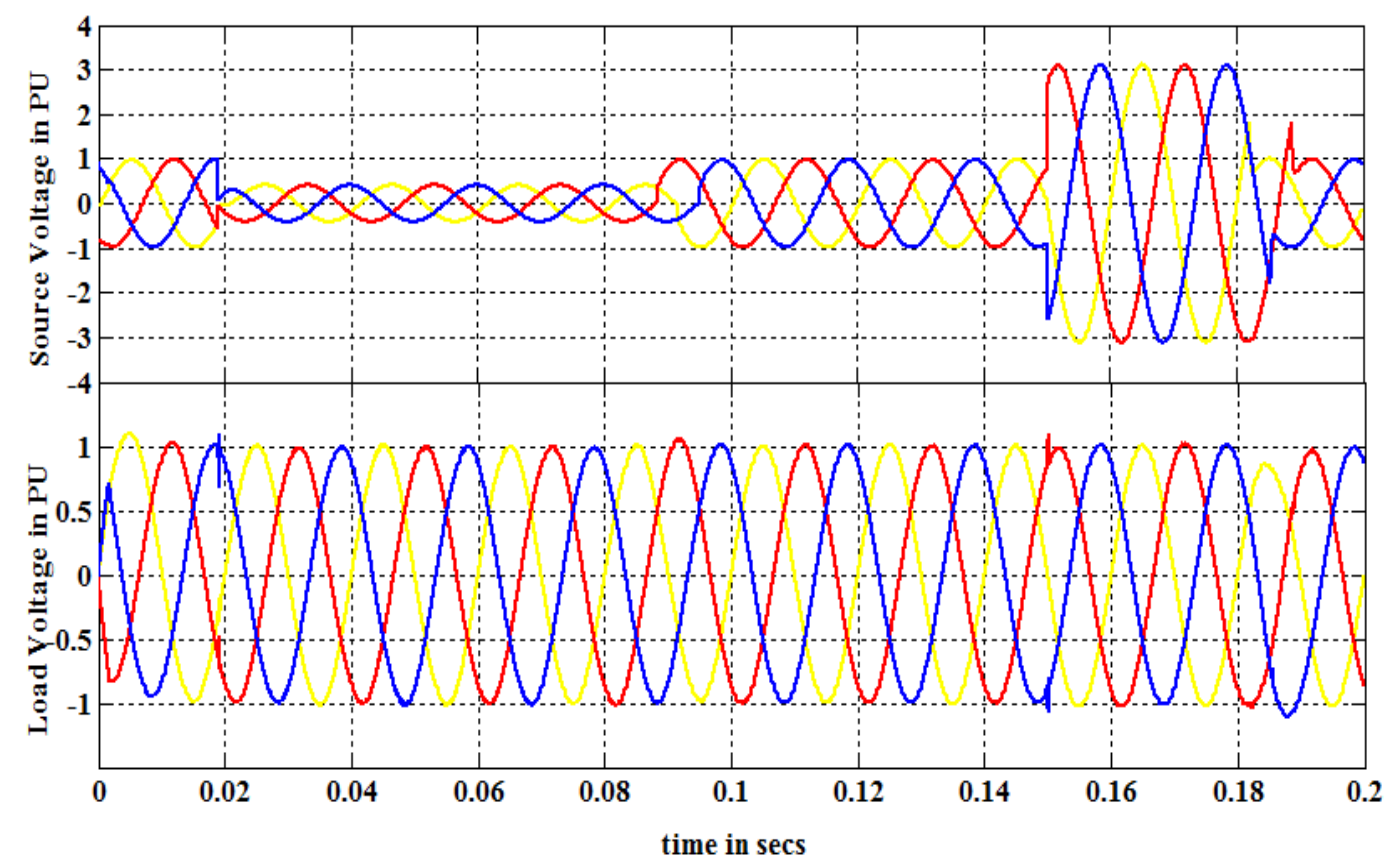

Figure 12. Magnitude of voltage of test system without and with PI controlled DVR

Fuzzy Controller is designed to compensate the power quality problems occurred during fault conditions for the system considered with DVR. Fig. 13 shows the magnitude of load voltage after mitigating the sag and swell conditions by implementing proposed FLC based PV fed DVR.

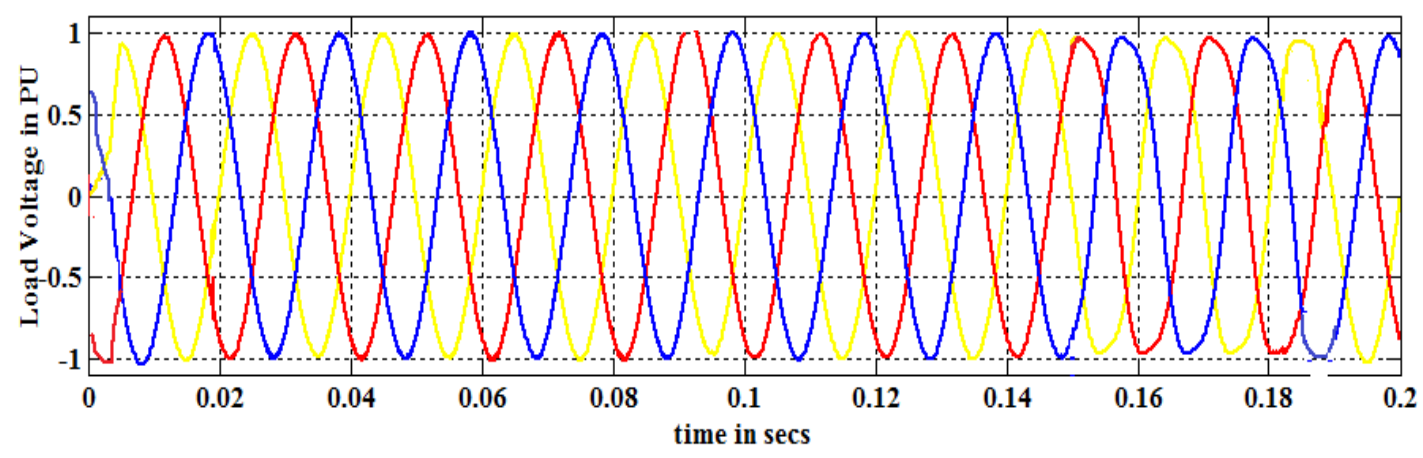

Figure 13. Magnitude of Load Voltage of test system with Fuzzy controlled DVR

For above case study, the Total Harmonic Distortion (THD) is also reduced by implementing Fuzzy controller and represented by using FFT Analysis. Fig. 14 \& Fig. 15 represents the \%THD without DVR and with PV based DVR using PI Controller. Fig.16 shows the reduction of \%THD by implementing the proposed DVR using FLC controller in the test system considered. The THD is reduced to $1.85 \%$ by using FLC based DVR. 


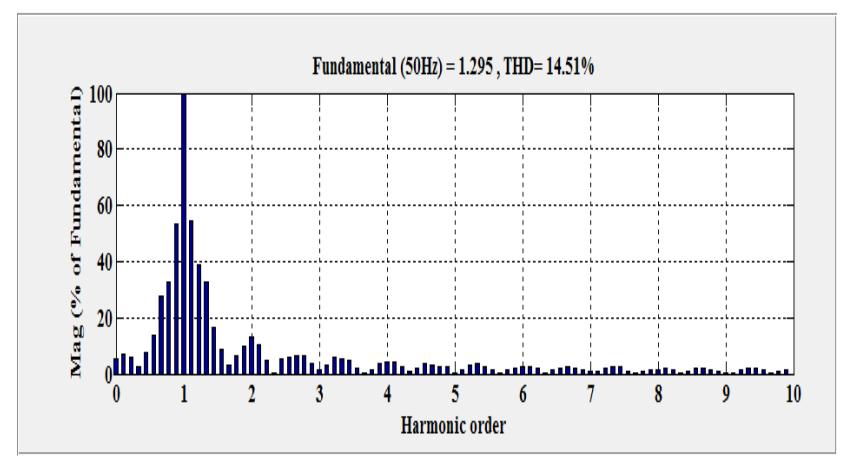

Figure 14. FFT analysis during fault condition

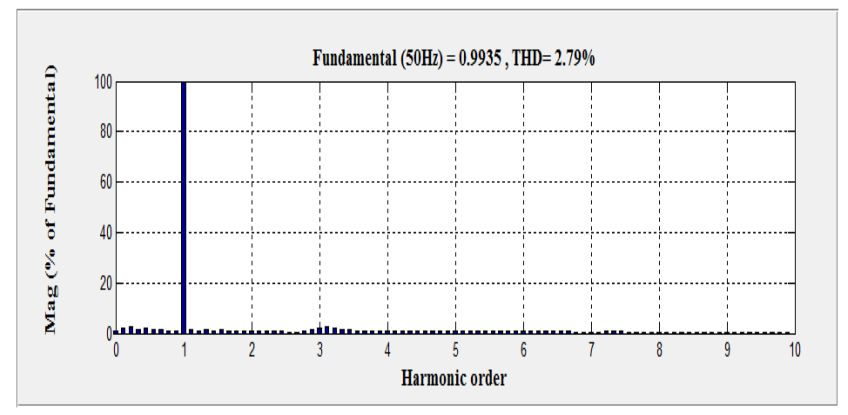

Figure 15. FFT analysis by implementing PI controlled DVR

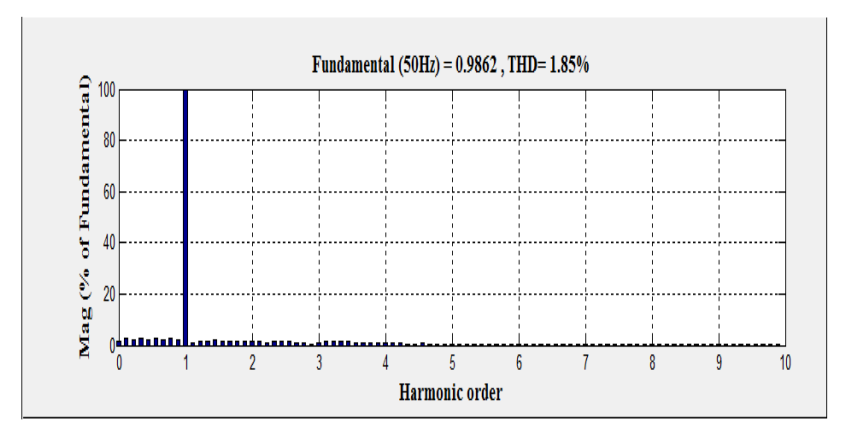

Figure 16. FFT Analysis by implementing Fuzzy controlled DVR

The combination of sag, swell and interruption conditions are observed for the considered test system. The swell is applied between $0.1 \mathrm{~s}$ and $0.15 \mathrm{~s}$, sag from $0.25 \mathrm{~s}$ to 0.35 and interruption between $0.45 \mathrm{~s}$ and $0.55 \mathrm{~s}$. Fig. 17(a) and Fig. 17(b) shows the magnitude of voltages before and after mitigation of above mentioned power quality problems by implementing proposed DVR. The injected voltage from proposed DVR is shown in Fig.17(c). 

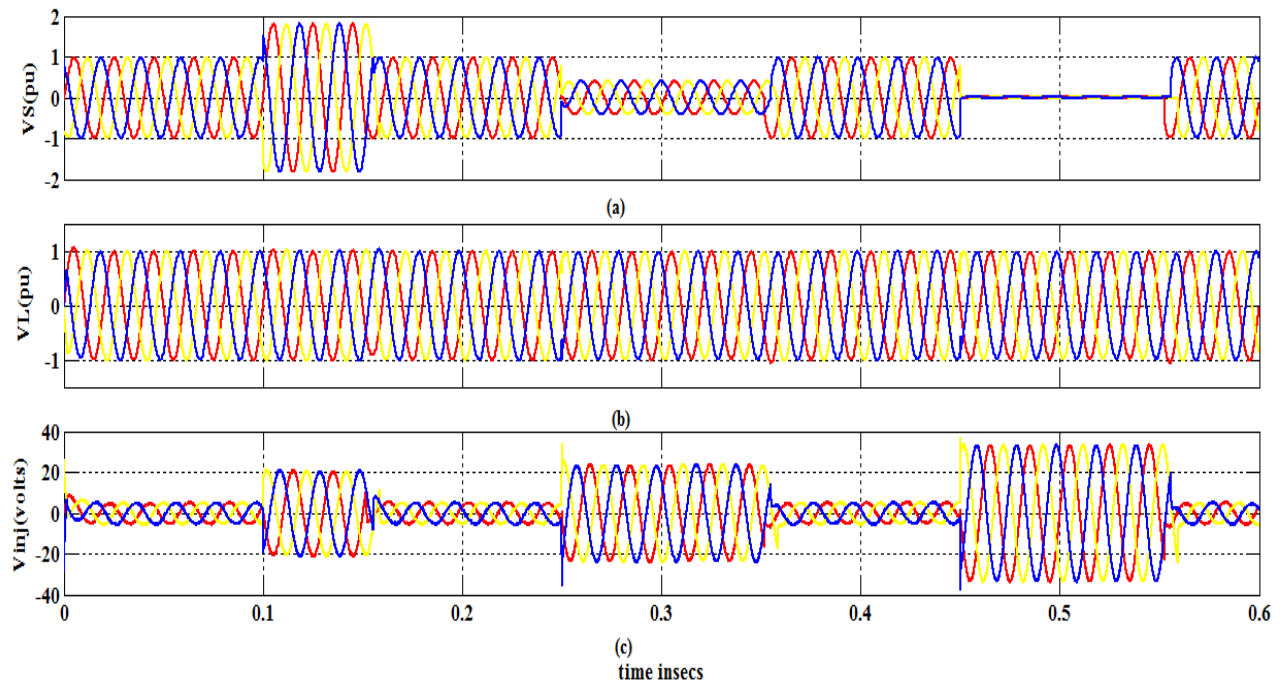

Figure 17. Magnitudes of source, load and injected voltages by using Fuzzy controlled DVR during the combination of sag, swell and interruption

The test system is also simulated for various fault conditions and the power quality problems are observed. Table 5 represents the comparison results of PV based DVR with PI controller and PV based DVR with Fuzzy controller for different types of faults. From the results it is observed that the total harmonic distortions are significantly reduced by implementing PV based DVR with fuzzy.

Table 5. Comparison of FFT analysis for various faults by using PV based DVR with PI and fuzzy

\begin{tabular}{|c|c|c|c|c|}
\hline & & & \multicolumn{2}{|c|}{ FFT Analysis } \\
\hline $\begin{array}{c}\text { PQ } \\
\text { problem }\end{array}$ & Type of Fault & Without DVR & $\begin{array}{c}\text { PV Based DVR } \\
\text { with PI }\end{array}$ & $\begin{array}{c}\text { PV Based DVR with } \\
\text { Fuzzy }\end{array}$ \\
\hline \multirow{4}{*}{$\begin{array}{l}\text { Voltage } \\
\text { Sag }\end{array}$} & $\begin{array}{l}\text { Three phase fault } \\
\text { (L-L-L) }\end{array}$ & $5.41 \%$ & $2.36 \%$ & $0.44 \%$ \\
\hline & $\begin{array}{l}\text { Three phase to } \\
\text { ground fault(L-L-L- } \\
\text { G) }\end{array}$ & $4.23 \%$ & $2.27 \%$ & $0.43 \%$ \\
\hline & $\begin{array}{l}\text { Single line ground } \\
\text { fault(L-G) }\end{array}$ & $2.75 \%$ & $1.53 \%$ & $0.55 \%$ \\
\hline & $\begin{array}{l}\text { Double line ground } \\
\text { fault(LL-G) }\end{array}$ & $5.91 \%$ & $2.20 \%$ & $0.51 \%$ \\
\hline $\begin{array}{l}\text { Voltage } \\
\text { Swell }\end{array}$ & Three phase fault & $7.93 \%$ & $2.23 \%$ & $0.46 \%$ \\
\hline \multicolumn{2}{|c|}{ Voltage Sag and Swell } & $14.51 \%$ & $2.79 \%$ & $1.85 \%$ \\
\hline
\end{tabular}


International Journal of Fuzzy Logic Systems (IJFLS) Vol.6, No.2,April 2016

\begin{tabular}{|c|c|c|c|}
\hline Interruption & $4.40 \%$ & $2.49 \%$ & $0.54 \%$ \\
\hline $\begin{array}{c}\text { Voltage Sag, Swell and } \\
\text { Interruption }\end{array}$ & $2.64 \%$ & $1.35 \%$ & $0.40 \%$ \\
\hline
\end{tabular}

\section{CONCLUSIONS}

Power Quality enhancement has become a significant scenario in recent years. In this paper fuzzy logic controlled Dynamic Voltage Restorer fed with fuzzy based Photo Voltaic System is proposed to mitigate the power quality problems. The performance comparison of the controllers based on harmonic reduction is done. The results show the proposed DVR using FLC gives better compensation when compared with PI controller. The total harmonic distortions (THD) are also reduced by implementing Fuzzy controller in the DVR.

\section{REFERENCES:}

[1] Alexander Eigels, Emanuel, John A. Mcneill "Electric power quality" ,annu.Rev.Energy Environ 1997,pp.264-303.

[2] A. Ghosh and G. Ledwich, "Compensation of distribution system voltage using DVR", IEEE Transactions on Power Delivery, Vol. 17, pp. 1030-1036, October., 2002.

[3] Singh, M., Khadkikar, V., Chandra, A. and Varma, R. K., "Grid Interconnection of renewable Energy Sources at the Distribution Level with Power Quality Improvement Features," IEEE Transactions on Power Delivery, Vol. 26, No. 1, pp. $307315,2011$.

[4] K. H. Hussein, I. Muta, T. Hoshino, and M. Osakada, "Maximumphotovoltaic power tracking: An algorithm for rapidly changingatmospheric condition,"Inst. Elect. Eng. Proc.-Gener. Trans. Distrib.,vol. 142, no. 1, pp. 59-64, 1995.

[5] Elgendy MA, Zahawi B, Atkinson DJ.,“ Assessment of perturb and observe MPPT algorithm implementation techniques for PV pumping applications.”, IEEE Trans Sustain Energy 2012;3(1):2133.

[6] Strzelecki R, Benysek G. "Control strategies and comparison of the dynamic voltage restorer". In: Proc power quality and supply reliability conference; 2008. p. 79-82.

[7] Majid Moradlou, Hamid R. Karshenas, “ Design Strategy for Optimum Rating Selection of Interline DVR", IEEE Transactions on power delivery, Vol. 26, No. 1, January 2011.

[8] Roger C Dugan, "Electrical Power System Quality". McGraw-Hili Prof Medrrech, 26-Nov-2002.

[9] NIELSEN J.G. , BLAABJERG F. ,"A detailed comparison system topologies for dynamic voltage restorers", IEEE Trans. Ind. Appl., 2005,41, (5), pp. 1272 - 1280

[10] M.J. Newman, D.N.Zmood, D.G.Holmes, "Stationary frame harmonic reference generation for active filter systems", IEEE Trans. on Ind. App., Vol. 38, No. 6, pp. 1591 - 1599, 2002.

[11] M G. Villalva, J. R. Gazoli, E. Ruppert F, "Comprehensive approach to modeling and simulation of photovoltaic arrays", IEEE Transactions on Power Electronics, 2009 vol. 25, no. 5, pp. 1198--1208, ISSN 0885-8993.

[12] M. M. Algazar, H. Al-Monier, H. A. El-Halim, and M. E. E. K. Salem, "Maximum power point tracking using fuzzy logic control," International Journal of Electrical Power and Energy Systems, vol. 39, no. 1, pp. 21-28, 2012.

[13] Semwal, Vijay Bhaskar, Pavan Chakraborty, and G. C. Nandi. "Less computationally intensive fuzzy logic (type-1)-based controller for humanoid push recovery." Robotics and Autonomous Systems 63 (2015): 122-135. 